\title{
Methods of Contemporary Sanad Hadith Criticism: (Study on The Understanding Perspective of Middle Eastern Hadith Scholars)
}

\author{
$1^{\text {st }}$ Rizkiyatul Imtyas ${ }^{1}, 2^{\text {nd }}$ Ahmad Fudhaili Hasyim ${ }^{2}, 3^{\text {rd }}$ Muhammad Ishar Helmi $^{3}$ \\ \{rizkyatul_imtyas19@mhs.uinjkt.ac.id ${ }^{1}$, ahmad.fudhaili@uinjkt.ac.id², izharhelmi@uinjkt.ac.id ${ }^{3}$ \} \\ UIN Syarif Hidayatullah Jakarta ${ }^{1,2,3}$
}

\begin{abstract}
This study aims to analyze the critical method of sanad hadith used by several contemporary hadith scholars in the Middle East. The results of it are focused on the tendencies and characteristics of the methods used by them. This study used library research and qualitative methods which are arranged descriptively, comparatively, and analytically. This research departs from the statement put forward by Daniel Djuned and Ahmad Amin (d. $1373 \mathrm{H})$ they said the study of sanad hadith criticism is no longer relevant in the contemporary era. According to researchers, studies on sanad hadith are no less important to study, especially in the current era, there have been many circulating hoaxes or $d a$ 'if claims or sahịh claims against unfounded hadiths to support the ideology of a group.
\end{abstract}

Keywords: Hadith, Hadith Criticism, Hadith Criticism Method, Contemporary Hadith Critics.

\section{Introduction}

The Middle East region is considered the center of hadith studies in the world, many of the Muslim scholars have studied in several Middle Eastern regions. Terminologically, according to the theory of Long David E and Reich Bernad, which explains that the term the Middle East is closely related to ethnocultural and ethnoreligious elements [1]. From an ethnocultural perspective, the Middle East is used to refer to countries that are dominated by Arabs and their culture. Meanwhile, according to ethnoreligious elements, the term Middle East is used to refer to countries where most of the people follow Islam, in other words, the influence of Islam has a dominant influence. This theory concludes that the two factors above become an inseparable series [2], this also implies that the Middle East region is often referred to as the Arab and Islamic world.

Concerning the study of hadith, the Middle East region has a major contribution to the development of hadith studies in the world. This is because the area is the birthplace of Islam itself, so that religious narratives appear there and become a heritage that has always been preserved from the classical era to the present. Many formal and non-formal Islamic study and education institutions in the Middle East concentrate on the study of hadith, this is a special attraction for students all over the world to study hadith there. The existence of this research institution has also succeeded in producing several scholars who are recognized for their credibility, both classical and contemporary. 
Some contemporary hadith critics of Middle East alumni are Hasan bin Ali Assaqaf, Abdul Basith Mazid, Said Mamduh, and Habiburrahman al-A'dzami. They are hadith scholars who have received education in the Middle East and each of them has made a major contribution to the science of hadith and its dynamics, both through writings and through studies organized to educate the Muslim community. In addition to studying hadith studies, the four scholars are also competent in theology, Islamic science, Islamic thought, and so on. Some of them are also active lecturers who teach at several universities in the world.

The presence of the four figures above and their contribution to hadith criticism is a tangible form that the praxis of hadith criticism in the contemporary era still exists. The researcher does not agree with the argument put forward by Daniel Djuned, who explains that the study of hadith criticism is no longer relevant in the contemporary era [3], meaning that the study of hadith criticism has been completed and should only be remembered by hadith scholars. Likewise, explained by Ahmad Amin (d. $1373 \mathrm{H}$ ) that the criticism of hadith has been completed by classical hadith critics and the main task of contemporary hadith critics is to study the understanding of hadith only [4].

In fact, in the contemporary era, the study of hadith is needed to provide a comprehensive understanding to the public, but the study of hadith sanad is no less important to study, especially in the current era there are many hoaxes or da'if claims or sa claims against hadiths that do not exist. fundamental to support the ideology of an individual. In addition, according to the opinion of Thahir al-Jawabi [5], a hadith can be analyzed further if the hadith is authentic or hasan. Therefore, the study of the sanad of hadith is indispensable and timeless.

In conducting criticisms of the sanad against al-Albani [6], the four hadith scholars put all their critical aspirations in the books they wrote, such as Tanāqựāt al-Albāni al-Wādihhāt by Hasan bin Ali Assaqaf, Tanbīh al-Muslim ilā Ta'add̄̄ al-Albāni 'alā aḥ̄ḥ Muslim by Said Mamduh, al-Ta'āqubāt al-Hadīthiyyah 'alā al-Shā̄kh al-Albāni Abdul Basith Mazid, al-Albāni: Shużūżuhū wa Akhțā'uhū by Habiburrahman al-A'dzami. Through these works, of course, they have their methods and characteristics that are used as benchmarks for carrying out hadith criticism. Then have they unknowingly contributed to a new formulation or rule in the world of hadith criticism or just confirmed the formulation of hadith criticism that has been set by classical hadith critics?

\section{Methodology}

The method used is library research, qualitative by using comparative analytical descriptive method. To strengthen the analysis, I used the critical method of sanad and matan hadith, this method was carried out to determine the authenticity of the sanad and matan hadith. This method also begins with takhrij hadith to trace hadith incredible literature. To explore how contemporary Middle Eastern hadith scholars think, I use the character study method. This method is also used to find the differences and similarities of each character's thoughts. 


\section{Result and Discussion}

\subsection{Definition of Hadith Criticism}

Before discussing further the methods of contemporary hadith critics, the researcher will first explain the word "criticism" which has multiple interpretations. When you hear the word criticism, most Indonesians often think of criticism with a negative connotation, even though in its application it is not always like that. In detail, if the word criticism is used to describe a correction of an error in something, it tends to have negative implications. If it is related to the dimension of hadith science, the context of such understanding seems to give the impression that hadith criticism is "there is an error in the hadith of the Prophet" and needs to be "criticized" which means "correction/revision". This impression is also found in the daily conversations of Indonesians who place the word criticism on the meaning of not being quick to believe, sharp in analysis, and considering the good or bad of work [7].

The word critique will have a different meaning according to the context in which the word is used. The word criticism can have a positive connotation if it is interpreted as an attempt to make judgments about the good or bad of a thing/to make judgments about the good and bad points. Criticism with a positive denotation also involves various rational and objective considerations when assessing something. In contrast to criticism with negative denotations, which are more to judge with disapproval, namely judging something with rejection [8]. Meanwhile, "rejection" or a priori tends to be oriented towards subjective blind judgment because it is based on the negation of the object being assessed.

According to the researcher, from the explanation above, the position of hadith criticism is included in the category of positive criticism, because hadith critics place themselves in an objective position to assess hadith and their narrators, such as efforts to answer the question: "is the content of the hadith valid and can it be historically corrected?" accountable or not?". Hadith critics also refer to the prevailing standardization of hadith criticism. An objective attitude is applied by hadith critics as the main parameter to avoid bias (bias contrast effect) and subjectivity that can damage the truth value of Muslim hadith studies [9].

Hadith criticism, in Arabic terminology, is known as naqd al-hadith which is the root of the words naqd and al-hadīth. Al-Naqd in Arabic means; checking, research, analysis, and differentiation [10].

\subsection{Sanad Hadith Criticism Formulation Used by Middle Eastern Scholars in the Contemporary Era}

After understanding the terms of hadith criticism, we will discuss the findings of the characteristics of contemporary hadith scholars, especially from the perspective of Middle Eastern scholars. As explained in the introduction, the researchers took samples [11] from their works on critical responses to the al-Albani hadith method. the works studied are the book

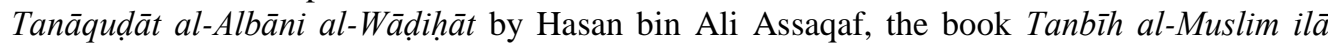
Ta'add̄ al-Albāni 'alā aḥ̄h Muslim by Said Mamduh, the book al-Ta'āqubāt al-Hadīthiyyah 'alā al-Shā̄kh al-Albāni by Abdul Basith Mazid, Kitab al-Albāni: Shużüzhū wa Akhțā'uhū by Habiburrahman al-A'dzami.

After an in-depth analysis, the researcher argues that several methods of hadith criticism that are generally used by Middle Eastern hadith critics in the contemporary era are as follows: 


\subsubsection{Making Al-Bukhari and Muslim Standards as References in Criticizing Sanad Hadith}

After analyzing, mainstream contemporary Middle Eastern hadith critics use the criteria for hadith validity formulated by al-Bukhari and Muslim as standardization when criticizing al-Albani. These efforts were made to trace the authenticity of the hadith, especially in its sanad [12].

The reason for the selection of the criteria for the validity of the hadith is because the parameters used by al-Bukhari and Muslim are considered to have gone through a rigorous selection and the research stages are not short, resulting in an accurate standardization of sanad criticism. The second reason is that when viewed from the character of the two, both al-Bukhari and Muslim both have good personalities, they are also famous among world scholars as well-known hadith experts nowadays.

As Said Mamduh's argument, he quotes the words of Ibn Salah:

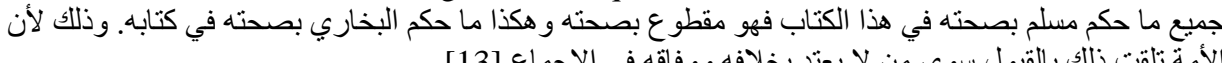

"All the hadiths which have been confirmed as authentic by Imam Muslim in this book (Șahịh Muslim) are authenticated, and so are the hadiths which have been confirmed as authentic by Imam al-Bukhari in his book. This is because (the majority) of the ummah have agreed except for those whose differences and agreements do not need to be considered by ijmā"'.

In addition, Said Mamduh through his book Tanbīh al-Muslim ilā Ta'addī al-Albāni 'alā aḥịh Muslim says that all series of sanad and narrators of hadith in the book șahịhain (Șahịị al-Bukhārī and Șaḥịh Muslim) have mutawātir, thiqqah, 'ādil and ḍabīṭ qualities, so there is no need to question its credibility [13].

From Said Mamduh's explanation, he provides several arguments regarding the consequences of debating the sanad in the book of șahịhain, especially for contemporary society today, the consequences in question are as follows:

a. Gives a bad impact on ordinary people who do not understand the dynamics of hadith science and criticism of sanad.

b. Debating the sanads in the book of șahịhain is considered the same as violating the ijmā or the agreement of the majority of religious scholars, and most of them are people who memorize a lot of the hadith of hufāz al-ḥadīth and have contributed to the hadith.

c. Debating the sanads of șaḥhhain is like belittling the credibility of Imam al-Bukhari and Muslim.

d. It is advisable for Muslims to taqlìd or believes in the authenticity and validity of the Șahīh al-Bukhāri and Muslim sanad. Because in conducting the selection of hadith narrations, they are both considered strict and have been tested for accuracy by other hadith scholars. In addition, the conditions used by al-Bukhari and Muslim are also used as a reference by many scholars in the application of sanad criticism until now [13].

Abdul Basith Mazid also used the criteria of Șahīh al-Bukhari and Muslim as a benchmark in conducting criticism of hadith. It is proven when he criticizes al-Albani's assessment in the hadith as follows:

First, Abdul Basith considered that al-Albani used the rules of hadith criticism which were considered irrelevant to most scholars of hadith experts in general. In detail, al-Albani is proven to use rules that are considered weak by most scholars of hadith experts. As one 
focus of his criticism, Abdul Basith in his book al-Ta'āqubāt al-Hadīthiyyah 'alā al-Shaīkh al-Albānī explains that al-Albani dares to violate the value of the riwayahs of hadith that have been collected in the books of Șaḥị̣ al-Bukhārī and Șahīḥ Muslim. Al-Albani argued that the steps he took were following previous scholars, such as al-Daruquthni. Meanwhile, according to Abdul Basith's research, al-Daruquthni uses weak rules in criticizing the riwayah hadiths of Sahīh al-Bukhārī. On the other hand, most of the hadith scholars who lived contemporaries of al-Bukhari and Muslim have tested and agreed on the validity of the standardization he used in selecting his authentic hadith [14].

Second, when criticizing al-Albani, Abdul Basith uses the Imam Muslim standard which explains that the narration of a narrator who is contemporaneous with his teacher is accepted, but on the condition that the narrator must be thiqqah and not a mudallis [14].

Thrid, Abdul Basith said that the use of 'an'anah in the books of Șạịh al-Bukhari and ahīh Muslim does not indicate the practice of tadlīs, but simā'. This is because considering that Imam Bukhari and Muslim are considered very strict in selecting and researching the narrators studied, so there is no doubt that the narrators in the two books are guaranteed to be accurate and are not classified as ḍa'if narrators [14].

According to Abdul Basith, Hasan bin Ali Assaqaf and Said mamduh, the statements regarding the accuracy of Șahīh al-Bukhāri and Șaḥị Muslim were not born from their independent analysis alone, but are also an affirmation of the theories of classical hadith scholars.

\subsubsection{Using Psychological, Geographical Approaches and Rational Studies in Understanding the Character of the Jarh Wa Al-Ta'dīl Scholars}

As for the focus of the practice of hadith criticism from the perspective of contemporary Middle Eastern scholars, one of them uses several approaches such as rational studies, psychological and geographical approaches that are used to interpret jarh wa al-ta'dl terms and analyze the background of scholars. which gives the two labels (jarh and al-ta'dīl).

This effort was made because the background of jarh wa al-ta'dìl scholars and their interpretations could affect the final result of the assessment of a narrator. Here are some examples of this practice:

Rational Study

Hasan bin Ali Assaqaf uses a rational approach and a psychological approach in analyzing the words of hadith critic scholars when assessing a narrator. Some of these approaches are used to seek validity by the reality that exists when a hadith critic gives a jarh or ta'dl assessment of someone. The data obtained using these approaches are then analyzed, compared and considered to produce accurate conclusions following the jarh wa al-ta'dīl rules.

For example, when Hasan bin Ali Assaqaf criticized al-Albani who followed Shu'bah's opinion to give Abu Zubair a jarh label. In this case, Assaqaf found the reason why Shu'bah labeled Abu Zubair with jarh, because Abu Zubair was considered bad in his prayers. According to Assaqaf, Shu'bah's statement had implications for the rejection of Abu Zubair's narration because it did not meet one of the requirements for the validity of the sanad hadith. However, in response to the Shu'bah claim, Hasan bin Ali Assaqaf tried to analyze it with a ratio approach. Assaqaf argues that if Shu'bah's statement is considered multiple interpretations, it could contain an element of subjectivity that leads to differences of opinion on one of the characteristics of prayer between Shu'bah and Abu Zubair. 
Assaqaf then analogized the case with one of Ibn al-Qatthan's opinions [15] that in the history of madhab fiqh, Imam Shafi'i also looked bad or bad at the prayer movements practiced by Imam Hanafi, and vice versa. But the bad meaning here is not a negative thing, but because there are differences of opinion in applying the characteristic of the Prophet Saw's prayer. So in the case of Shu'bah's statement about the badness of Abu Zubair's prayer, it could mean that they were different schools of thought in the practice of the Prophet's prayer. If so, then it is not an easy matter to claim that Abu Zubair is considered unfair just because of one statement from the Shu'bah. On the other hand, in terms of quantity, the hadith critics who labeled Abu Zubair ta'dīl proved to be more than those who labeled jarh [12].

Abdul basith Mazid also uses a rational approach in the criticism of hadith sanad. Precisely, when he gave a critique of al-Albani who was considered irrational in the application of the rules of connection of the hadith sanad. In this case, al-Albani gave the label "dạf'if" an assessment of one of the traditions contained in the book Șahīh al-Bukhārī number 2855. After analyzing, according to Abdul Basith, the reason al-Albani judged da'îf the hadith was because he did not agree with one of the one conditions for the continuity of the chain which was initiated by al-Bukhari, namely the necessity of a narrator to meet his teacher when narrating a hadith. Al-Albani argued that the necessity of being contemporaneous with the narrator's teacher was considered sufficient so that it was not necessary to confirm whether the narrator had met his teacher or not. Responding to al-Albani's understanding, Abdul Basith Mazid explained that if viewed from a rational point of view, contemporaries without meeting directly can guarantee the validity of hadith, especially contemporaries and face-to-face meetings, their validity is stronger. Moreover, al-Bukhari set this standard with a note that the narrator must be proven honest in his narration, this adds to the accuracy of the șahīh rule set by al-Bukhari [14].

Psychological Approach

Still in the case of jarh against Abu Zubair, in addition to using a ratio approach, Hasan bin Ali Assaqaf also analyzed the psychological influence of Shu'bah when assessing Abu Zubair's jarh. Hasan bin Ali Assaqaf found facts based on Ibn Hibban's statement in the book al-Thiqqät [16] which states that Shu'bah's psychological condition tends to be more temperamental because he was over 60 years old when he criticized Abu Zubair [12]. Therefore, Shu'bah's claims are considered subjective and need to be considered before assessing his judgment.

The explanation above leads to the conclusion that Abu Zubair is a narrator who is thiqqah and his hadiths can be narrated and used as ujjah. Because quantitatively the number of hadith critic scholars who label Abu Zubair ta'dl is more than the hadith critic scholars who give the label "jarh". In addition, most of them in giving the label "jarh" take Shu'bah statements whose authenticity is not necessarily valid and accurate. Then some of them who are independent of Shu'bah's statement, give a jarh assessment to Abu Zubair but it is not explained what the cause of the jār is therefore when referring to the jarh wa al-ta'dìl rule the claim is considered not strong [17].

Geographical approach

In addition to the two approaches above, the praxis of the sanad critique which is also the focus of contemporary Middle Eastern hadith critics is to use a geographical approach to determine the geographical conditions of the area occupied by a scholar when labeling jarh or ta'dīl on a narrator. As is the effort made by Habiburrahman al-A'dzami in providing an interpretation of the label "إنه مجهول" [18] which is used by Abu Hatim to catch a hadith narrator [19]. In this case, al-A'dzami cites the analysis of al-Sakhawi [20] and al-Dzahabi, 
they say that if Abu Hatim reads a narrator with the words " it does not mean that none of the other narrators have narrated from the narrator in question, but The narrator is majhūl in the perspective of Abu Hatim only [21].

On the other hand, Abu Hatim also gave a jarh label to a narrator named Daud bin Yazid al-Tsaqafi with the label "إنه مجهول". However, after doing research taking into account the geographical location the area where Daud bin Yazid lived with Abu Hatim was very far away, so he couldn't access information about Daud bin Yazid, this became the main reason why Abu Hatim gave the label "إنه مجهول" against Daud bin Yazid [21].

On the other hand, the researcher found many other hadith narrators who also narrated the hadith from Daud bin Yazid, besides that many other jarh wa al-ta'dīl scholars had access to Daud bin Yazid's personal data information. Therefore, this also underlies a rule in hadith criticism proposed by al-Sakhawi and al-Dzahabi that the labeling of jarh with the term "مجهول" which is attributed to Abu Hatim to a narrator cannot be used as hujjah if other critics find facts and information to negate the nature of the majhūl narrators of hadith [22].

\subsubsection{In-depth Analysis of the Interpretation of Terms in Jarh wa al-Ta'dīl}

Contemporary Middle Eastern hadith critics also pay a lot of attention to the use of terms in jarh wa al-ta'dīl. As Hasan bin Ali Assaqaf in criticizing al-Albani on the term Abu Hatim in the book al-Jarh wa al-Ta'dl. In more detail, the highlights of Abu Hatim's words are as follows:

حدثا عبد الرحمن قال سئل أبي عن محمد بن عمارة الذي يحدث عنه مالك فقال: هو صالح الحديث ليس بذاك القوي.

If you pay close attention, the words of Abu Hatim al-Razi above need a more detailed

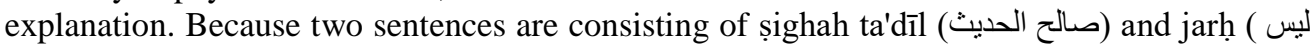
[18 in one narration simultaneously. So what is the purpose of those labels?

In the analysis of how the interpretation of the sighah, Hasan bin Ali Assaqaf adheres to the rules formulated by Mushtafa al-Adawi. It is stated that although Abu Hatim al-Razi is known as a mutashaddid critic, in this case, he categorizes Muhammad bin Umarah in the last level of $t a^{\prime} d \bar{l} l$, in other words, șighah "صالح الحديث" applies [12].

As for the faidah of the series of sentences, it is for the affirmation of Abu Hatim al-Razi that Muhammad bin Umarah is not included in the category of narrators al-asbāt al-aqwiyā' (the narrator who has the highest credibility in the ta'dīl level) for various reasons [12]. This then contradicts the argument of al-Albani who says that Muhammad bin Umarah holds the title muttarib al-hadìth [18] because of Abu Hatim's statement which he misunderstood.

Another example, when Hasan bin Ali Assaqaf criticizes al-Albani about how often he labels a hadith with the narration "لم أقف على سنده". In fact, according to him, those who have the authority to give this label are only well-known scholars from the mutaqaddimūn circle, because the study of the collection of hadith sanad and their selection is a complete study. Such attitude of al-Albani is considered to exceed and doubt the credibility of the criticisms of sanad and matan that have been carried out by previous hadith experts.

In his book Tanāquḍāt al-Albāni al-Wāḍihāat, Hasan bin Ali Assaqaf mentions several problems regarding the hadith which al-Albani claims does not have a sanad, but after a search of the hadith literature it turns out that these traditions have a complete sanad. Of course, the credibility of al-Albani's claim cannot be equated with previous scholars, which if the previous hadith critic scholars labeled "لم أقف على سنده", then the accuracy of the assessment can be ascertained, namely that a hadith does not have a sanad at all. This is because they are very strict in selecting hadith. It is common knowledge that to get a complete sanad, the previous 
hadith scholars were willing to travel to various areas with makeshift transportation just to get one riwayah that was complete and valid. Therefore, Hasan bin Ali Assaqaf considered that what al-Albani stated above was something strange and unusual. Repeating the same mistake, what al-Albani has done is judged for his lack of accuracy in takhrij hadith and studying several hadith narrations. So that the information about the sanad obtained there are many shortcomings.

Here are some examples of hadiths that al-Albani judged did not have a complete chain of sanad, but after an analysis by Hasan bin Ali Assaqaf, it turned out that the hadiths had complete sanad and their mukharrij [12].

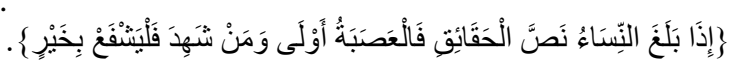

Al-Albani in his work entitled Irwā al-Ghalîl considers that the editorial above is " ل [23]. It should be noted that the meaning of the word " سند له" in the terminology of hadith science is the same as the term " which means a hadith that does not have a complete chain of sanad. If the label is intended for the assessment of hadith, it will have an impact on whether or not the hadith is allowed to be practiced as hujjah Muslims. It can be ascertained that the hadith is fake because it does not have a chain of sanad [18].

This was later denied by Hasan bin Ali Asssaqaf where he found the i'tibār of the hadith complete with its sanad and mukharrij name in the riwayah al-Baihaqi in his book entitled alSunan al-Kubrā as follows [24]:

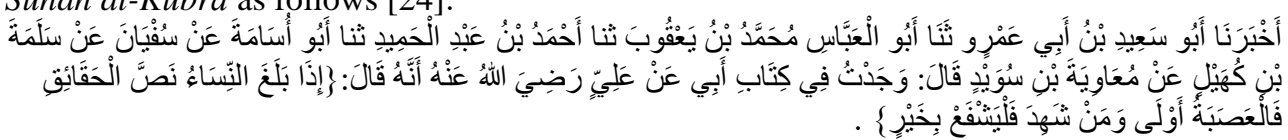

Even though this is an athār [18] from Ali bin Abi Talib ra and is not a hadith, but the citation of the athār with a sanad must certainly be traced and analyzed for authenticity. Because this can also be used as athar in sharia amaliyah and also adds scientific insight.

In addition to Assaqaf, Habiburrahman al-A'dzami considers the characteristics of the terms used by hadith critics in carrying out amaliyah jarh wa al-ta'dìl.

For example in the case of criticism of one of the narrators named Usaid bin Abi Usaid al-Barrad [25], al-Daruquthni said that Usaid was judged jarh with the label "يُعتبر ". At first glance, "يُعتبر" is a term commonly used by jarh wa al-ta'dīl scholars to label ta'dīl to a narrator. As for the interpretation of "يُعتبر " is something good, in terms of jarh wa al-ta'dìl, the term is on the same level as the term "يُعنبر" ". According to al-Sakhawi the term is at the sixth ta'dīl level which indicates the meaning:

$$
\text { يكتب حديث أهلها وينظر فيه للاعتبار. }
$$

"The narration is still accepted but further research is still being carried out on the condition of the narrator" [18].

Habiburrahman al-A'dzami explained that if Daruquthni said " يُعتبر " to a narrator, then what he meant was that the narrator was " لا يحتاج به" or could not be used as hujjah and was not an indication of the meaning of $t a^{\prime} d \bar{l} l$ as already mentioned.

This is based on al-A'dzami's analysis and observation of the characteristics of the term and the characteristics of the jarh wa al-ta'dìl scholars in giving their criticisms. He emphasized that paying attention to the characteristics of these terms is very important and cannot be underestimated, because it can affect the quality of the hadith in a riwayah as a whole. In this book, he rejects al-Albani's method which is less thorough in paying attention to the terms of the scholars of hadith criticism, thus indicating many mistakes in concluding the status of hadith. which in this case al-Albani argues that the term "بحتبنبر به" [21] which comes from alDaruquthni is a $t a^{\prime} d \bar{l} l$ expression which is on the same level as the terms sadīq and $l \bar{a} b a$ 'sa $\operatorname{bih} \bar{\imath}[18]$. 
As also explained by Sayyid Abdul majid al-Ghouri that the meaning of the second level of the term $t a^{\prime} d \bar{l} l$ is:

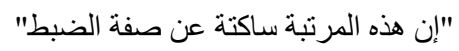

"This level is meaningful if the narrator of hadith has less memorization power (al-ḍat)" [18].

\section{Conclusion}

This study succeeded in refuting the arguments of Daniel Djuned and Ahmad Amin (d. $1373 \mathrm{H}$ ) who said that the study of hadith criticism is no longer relevant in the contemporary era. As done by contemporary Middle Eastern hadith critics. The form of praxis in the criticism of the hadith sanad by contemporary Middle Eastern hadith scholars is in the form of education, verification between scholars of hadith critics related to the authenticity and validity of a sanad and matan hadith that will be studied. Contemporary Middle Eastern hadith critic scholars tend to compare the labeling of ulama jarh wa al-ta'dil then analyze and give in-depth interpretations to produce a conclusion from a more accurate sanad criticism.

Although broadly speaking, the urgency of the contemporary Middle Eastern hadith critics is to emphasize the technicalities of classical hadith criticism, they have also succeeded in presenting several new formulations as instruments to get a more accurate conclusion on hadith criticism. Contemporary Middle Eastern hadith critics tend to think more rationally by using a psychological, geographical approach to analyze a hadith narrator.

The main factor why they use this method is because they are academics who are active in the development of science. In addition, there are research demands in the contemporary era with all its methodological aspects. The position of the hadith critic is to make the classical hadith critic method readable by current academics by integrating empirical research methods.

\section{References}

[1] David E, Long dan Bernard Reich, The Goverment and Politics of the Middle East and North Africa, Colorado: Westview Press, 1980.

[2] Kholil Arkram Hakim, Konflik Timur Tengah dalam Perspektif Geopolitik, UIN Sunan Kalijaga Yogyakarta, 2016.

[3] Daniel Djuned, Paradigma Baru Studi Ilmu Hadis, Aceh: Citra Karya, 2001.

[4] Ahmad Amin, Fajr al-Islām, Kairo: Mu'assasah al-Hindawī li al-Ta'līm wa al-Thaqofah, 2012.

[5] Muhammad Tahir al-Jawabi, Juhüd al-Muhaddithīn, Tunisia: Mu'assasah 'Abd al-Karīm, 1986.

[6] Mubarak bin Mahfudh, Biografi Syaikh al-Albani Mujaddid dan Ahli Hadits Abad ini, Bogor: Pustaka Imam Al-Syafi'i, 2003.

[7] Departemen Pendidikan dan Kebudayaan, Kamus Umum Bahasa Indonesia, Jakarta: Balai Pustaka, 1988.

[8] Longman, Dictionary of Contemporary English, (Oxford: Oxford University Press, 1988.

[9] John Burton, An Introduction to the Hadith, Edinburgh: Edinburgh University Press.

[10] Hans Wehr, A Dictionary of Modern Written Arabic, London: George Allen \& Unwin Ltd., 1970 M.

[11] P. Joko Subagyo, Metode Penelitian dalam Teori dan Praktek, Jakarta: Rineka Cipta, 1991.

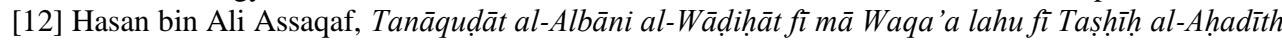
wa Taụ' 'îfihà min al-Akhțā' wa al-Ghalațāt, $1^{\text {st }}$ ed. al-Maktabah al-Takhașșușiyyah li al-Rad 'alā alWahabiyyah, 2007. 
[13] Mahmud Said Mamduh, Tanbīh al-Muslim ilā Ta'add̄̄ al-Albāni 'alā Sahīh Muslim, Kairo: Maktabah wa al-Ṭaba'ah al-Mujalladah al-'Arabī, 2011.

[14] Abdul Basith Mazid, al-Ta'āqubāt al-Hadīthiyyah 'alā al-Shā̄kh al-Albānī, Kairo: Maktabah alİmān li al-Nașr wa al-Tauzī', 2013.

[15] Ibnu al-Qathan, Bayān al-Wahm wa al-Ilhām fì Kitāb al-Ahkām, $4^{\text {th }}$ ed. Riyad: Dār al-Ṭayyib, $1418 \mathrm{H}$.

[16] Muhammad Ibn Hibban, al-Thiqqāt, $5^{\text {th }}$ ed. India: Dāirah al-Ma'ārif al-Uthmāniyyah, 1973.

[17] Syuhudi Ismail, Kaedah Kesahihan Sanad Hadith, Jakarta: Bulan Bintang. 1995).

[18] Abdul Majid al-Ghauri, Mu'jam al-Mușțalahāt al-Hadìthiyyah, Beirut: Dār Ibn al-Kathīr, 2007.

[19] Abu Hatim al-Razi, al-Jarh wa al-Ta 'dīl, $8^{\text {th }}$ ed. Beirut: Dār Ihyā' al-Turāth al- 'Arabī, 1952.

[20] Al-Sakhawi, Fath al-Mughīth bi Sharh Alfiyah al-Hadīth li al-'Irāqi, $2^{\text {nd }}$ ed. Kairo: Maktabah AlSunnah, 2003.

[21] Habiburrahman al-A'dzami, al-Albāni: Shużüżuhū wa Akhțā'uhū, $1^{\text {st }}$ ed. Kuwait: Maktabah Dār al-Ghurūbah lī al-Nashr wa al-Tauzī’, 1984.

[22] Muhammad Abdul Hay Al-Anshari, al-Raf'u wa al-Takmīl fì al-Jarh wa al-Ta'dīl Aleppo: Maktabah al-Maṭbū'āt al-Islāmiyah, 1407 H.

[23] Muhammad Nashiruddin Al-Albani, Irwā al-Ghalīl.

[24] Al-Baihaqi, al-Sunan al-Kubrāa, Beirut: Dār al-Kutub al-'Ilmiyyah, 2003.

[25] Ahmad ibn Hanbal, Musnad Ahmad bin Hanbal, Beirut: Muassasah al-Risālah, 1999. 